\title{
Vpliv različnih motečih dražljajev na prostorski delovni spomin
}

\author{
Martina Starc* in Grega Repovš \\ Laboratorij za kognitivno nevroznanost, Oddelek za psihologijo, Filozofska fakulteta, Univerza v Ljubljani
}

\begin{abstract}
Povzetek: Varovanje informacij pred različnimi motnjami je ključno za optimalno delovanje delovnega spomina. V študiji smo preverili, kako prisotnost motečih dražljajev vpliva na prostorski delovni spomin. Primerjali smo vpliv motečih dražljajev, ki izstopajo zaradi podobnosti tarčnim dražljajem ali zaradi negativne čustvene nasičenosti. Preverili smo vpliv na natančnost visoko ločljivih predstav, kot tudi na vpliv prostorskih kategorij, ter natančneje opredelili ne le obstoj, temveč tudi smer motečega vpliva (proti ali stran od motnje). Udeleženci ( $\mathrm{n}=25,8$ moških, 19-31 let) so si morali zapomniti natančen položaj prikazane premešane slike in ga po premoru obnoviti z igralno palico. V nekaterih poskusih je bila v času premora prikazana dodatna moteča slika (premešana, nevtralna ali negativna). Merili smo razpršenost odgovorov (kótnih napak) ter usmerjene premike proti prototipnim kótom $\left(45^{\circ}\right)$ in proti položaju motečih dražljajev. Prisotnost motečih dražljajev ni vplivala na razpršenost odgovorov, zmanjšala pa je težnjo udeležencev, da odgovore premikajo proti prototipnim kótom. Različne vrste slik se v tem učinku niso razlikovale. V nasprotju s pričakovanji so udeleženci odmikali svoje odgovore stran od položaja motečih slik; ta učinek je bil bolj izrazit pri negativnih slikah. Udeleženci pri reševanju naloge prostorskega delovnega spomina najverjetneje poleg natančnega pomnjenja položaja in vzdrževanja pozornosti na mestu dražljaja strateško uporabljajo tudi informacijo o pripadnosti prostorskim kategorijam (kvadrantom) ter informacijo o položaju motečega dražljaja. Odbojni učinek motečega dražljaja najverjetneje izhaja iz inhibicije njegovega položaja in kaže na potrebo po dopolnitvi računskih modelov prostorskega delovnega spomina ter upoštevanju različnih strategij uporabe delovnega spomina.
\end{abstract}

Ključne besede: delovni spomin, vidnoprostorski delovni spomin, moteči dražljaji, negativna čustva, smer motnje

\section{The influence of various distracting stimuli on spatial working memory}

\author{
Martina Starc* and Grega Repovš \\ Mind \& Brain Lab, Department of Psychology, Faculty of Arts, University of Ljubljana, Slovenia
}

\begin{abstract}
Protecting information from distraction is essential for optimal performance of working memory. We examined how the presence of distracting stimuli influences spatial working memory and compared the effect of both task-similar and negatively emotionally salient distractors. We checked the effect of distractors on the accuracy of high-resolution representations, as well as the maintenance of spatial categories, and more precisely defined not only the existence but also the direction of the distracting influences (towards or away from the position of the distractor). Participants ( $n=25,8$ men, 19-31 years old) were asked to remember the exact position of a target scrambled image and recall it with a joystick after a delay. In some trials an additional distracting image (scrambled, neutral or negative) was shown during the delay. We measured the spread of responses (standard deviation of angular error) and shifts of the average response towards the prototype angles $\left(45^{\circ}\right)$ or towards the position of distractors. Distracting stimuli did not affect the spread of responses and decreased the tendency of participants to move the responses towards the prototype angle. Different types of distractors did not differ in this effect. Contrary to expectations, the participants moved their responses away from the position of distractors; this effect was more pronounced for negative distractors. In addition to memorizing the exact position and maintaining attention on the position of the stimulus, participants are likely to strategically use information about spatial category membership (quadrants) and information about the position of the distractor. The repulsive effect of the distractor likely results from inhibition of its position and indicates the need to supplement computational models of spatial working memory and to take into account different strategies of working memory use.
\end{abstract}

Keywords: working memory, visuo-spatial working memory, distractors, negative emotions, direction of distraction

\footnotetext{
"Naslov/Address: Martina Starc, Laboratorij za kognitivno nevroznanost, Oddelek za psihologijo, Filozofska fakulteta, Univerza v Ljubljani, Aškerčeva 2, 1000 Ljubljana, e-pošta: martina.starc@psy.ff.uni-lj.si
} 
Delovni spomin, zmožnost kratkotrajnega pomnjenja in upravljanja $\mathrm{z}$ informacijami, je nujen za izvajanje vsakodnevnih nalog in spada med najpomembnejše izvršilne funkcije. Njegovo optimalno delovanje je odvisno od več različnih procesov, med katerimi je zelo pomembno varovanje informacij $\mathrm{v}$ delovnem spominu pred različnimi motnjami oz. motečimi dražljaji, ki tekmujejo za pozornost (Anticevic, Repovš in Barch, 2010; Dolcos, Diaz-Granados, Wang in McCarthy, 2008). Dražljaji so potencialno moteči, če so izstopajoči, bodisi zaradi zaznavne razločljivosti (npr. kontrasta), ujemanja s pozornostnimi filtri (Dolcos idr., 2008) ali čustvenosti (Dolcos, Kragel, Wang in McCarthy, 2006). Zmanjšana zmožnost inhibicije motečih informacij, še posebno če so le-te čustvene, je pomembna značilnost različnih čustvenih potez in motenj, kot so anksioznost (Fales, Becerril, Luking in Barch, 2010), depresija (Gruber, Purcell, Perna in Mikels, 2013; Joormann, Levens in Gotlib, 2011; Krause-Utz idr., 2012) in posttravmatska stresna motnja (Zhang idr., 2013).

Moteče učinke čustev na delovni spomin lahko najlažje pojasnimo preko vpliva na nadzorni del delovnega spomina-centralnega izvršitelja, ki se najbolj neposredno povezuje z zavestnim načrtovanjem (Repovš in Baddeley, 2006). Čustvene vsebine predstavljajo alternativen kontekst, soočanje z njimi pa dodatno nalogo, ki lahko preusmeri pozornost nase in zmoti tekoče izvajanje naloge (Pessoa, 2009). Vpliv na shranjevanje, vzdrževanje in priklic poteka posredno preko izvršilnega nadzora in usmerjanja virov.

Pri prostorskem delovnem spominu je možen tudi bolj neposreden vpliv na vkodiranje in vzdrževanje, in sicer preko mehanizmov pozornosti. Vzdrževanje položaja v delovnem spominu se poslabša, kadar naloga $\mathrm{v}$ času zamika pred odgovorom od udeležencev zahteva premike prostorske pozornosti (Awh in Jonides, 2001; Awh, Vogel in Oh, 2006; Corbetta, Kincade in Shulman, 2002). Prikriti premiki pozornosti so torej možen mehanizem vzdrževanja $\mathrm{v}$ prostorskem delovnem spominu. Kako na prostorski delovni spomin vplivajo čustveni dražljaji, še ni najbolje raziskano, kaže pa se, da je v primerjavi z besednim delovnim spominom bolj občutljiv na čustveno uravnavanje pozornosti (Shackman idr., 2006). Kadar čustveni dražljaji nastopajo v vlogi tarčnih dražljajev, lahko dodatna pozornost na čustvene vsebine izboljša delovni spomin za prostorska zaporedja (GonzálezGarrido, López-Franco, Gómez-Velázquez, Ramos-Loyo in Sequeira, 2015). Nasprotno pa pri motečih čustvenih dražljajih preusmerjanje pozornosti na čustveno vsebino zmoti delovni spomin. $Z$ nalogo nepovezan strah pred elektrošoki poslabša spomin za položaj (Lavric, Rippon in Gray, 2003), negativni moteči dražljaji pa vplivajo na evocirane potenciale, povezane s procesi delovnega spomina (Li, Chan in Luo, 2010).

Nekoliko bolje je raziskan vpliv motečih dražljajev na vidni delovni spomin. Dolcos in McCarthy (2006) sta npr. v nalogi vidnega delovnega spomina z odloženim odzivom pokazala negativen učinek negativnih čustvenih motečih dražljajev, prikazanih med vzdrževanjem spominskega niza. V drugi študiji so ta učinek primerjali tudi z dražljaji, ki so bili podobni spominskemu nizu (Dolcos idr., 2008). Razlike med podobnimi in čustvenimi motečimi dražljaji so se kazale predvsem v možganski aktivnosti - obe vrsti motečih dražljajev naj bi vplivali na isti proces, a v nasprotni smeri. Čustveni dražljaji deaktivirajo dorzolateralni prefrontalni korteks, kar naj bi odražalo tekmovanje za procesne vire preko inhibicije s strani amigdale in ventrolateralnega prefrontalnega korteksa (Dolcos in McCarthy, 2006). Nasprotno pa dražljaji, ki so podobni spominskemu nizu, dodatno aktivirajo dorzolateralni prefrontalni korteks, kar naj bi odražalo bodisi dodatne procesne zahteve pri nadzorovanju vsebine delovnega spomina bodisi delno vkodiranje motečih dražljajev v delovni spomin (Dolcos idr., 2008).

Tako pri besednem kot pri vidnem delovnem spominu lahko odgovore merimo le kategorično - udeleženci si zapomnijo predstavljene tarčne dražljaje, nato pa po premoru bodisi prikličejo informacije (npr. povedo, katero besedo so si morali zapomniti) bodisi prepoznajo, kateri dražljaj so si morali zapomniti (npr. izberejo pravilno od dveh prikazanih slik). Odgovore lahko tako kategoriziramo le dihotomno, kot napačne ali pravilne in ugotavljamo vpliv motečih dražljajev na pravilnost ali kapaciteto delovnega spomina preko vseh poskusov v izvedeni preizkušnji. Pri prostorskem delovnem spominu pa je zaradi narave prostorskih informacij mogoče iz poskusa $\mathrm{v}$ poskus spremljati natančnost odgovorov. Udeleženci lahko z usmerjanjem pogleda, kazanjem, klikom na miško ali premikom igralne palice ob priklicu obnovijo položaj prikazanega dražljaja, kar omogoča zvezno merjenje natančnosti. Predpostavljamo, da lahko na ta način povečamo moč statističnih testov in lažje zaznamo učinke čustev, ki so včasih težko zaznavni in merljivi (Kensinger in Corkin, 2003).

Prostorski delovni spomin je tudi živahno interdisciplinarno področje raziskovanja. S študijami, v katerih so merili aktivnost posameznih živčnih celic $\mathrm{v}$ možganih opic, so tako $\mathrm{v}$ prefrontalnem kot parietalnem korteksu našli piramidne celice, ki kažejo vzorec povečane aktivnosti ves čas premora med prikazom dražljaja in odgovorom, kar naj bi bil znak za vpletenost v procese delovnega spomina (Chafee in Goldman-Rakic, 1998; Funahashi, Bruce in Goldman-Rakic, 1989, 1990). Najpomembnejša ugotovljena značilnost teh piramidnih celic pa je selektivna občutlijivost na položaj oz. predvsem na kótno smer tarče (Funahashi, 2013). Nevroni, ki kodirajo položaj, se iz poskusa $\mathrm{v}$ poskus odzovejo le na določene kóte prikaza dražljajev. Piramidne celice, ki se odzivajo na določeno smer $\mathrm{v}$ prostoru, so preko povezovalnih celic inhibitorno povezane s piramidnimi celicami, ki kodirajo druge položaje (Goldman-Rakic, 1999). Na ta način so organizirane v spominska polja, ki spominjajo na vidna in motorična polja nevronov $\mathrm{v}$ vidnem in motoričnem korteksu (Goldman-Rakic, 1990). Spominsko polje prefrontalnega piramidnega nevrona je posledica tako ekscitatornih kot inhibitornih vplivov - dolgih povezav, ki prinašajo zaznavne informacije, in lokalnih povezav, ki prinašajo inhibitorne vplive 
nevronov z drugačno občutljivostjo na smer. Aktivacija preko celotne populacije nevronov natančno kodira smer, v kateri se je prikazala tarča.

Na podlagi ugotovitev nevrofizioloških raziskav so nastali podrobni računski modeli, ki omogočajo natančne napovedi vpliva motečih dražljajev (Compte, 2000). $\mathrm{Ob}$ prikazu tarčnega dražljaja se v na smer občutljivih piramidnih celicah vzpostavi vzorec aktivnosti, ki kodira položaj. Aktivnost je osredotočena na točen kót prikaza dražljaja, vendar je razpršena tudi preko nevronov, ki kodirajo podobne položaje. Vzdrževana aktivnost v času premora, ko tarčni dražljaj ni več prikazan, je nosilec informacije $\mathrm{v}$ delovnem spominu.

Natančnost prostorskega delovnega spomina je odvisna od moči signala $\mathrm{v}$ nevronih, ki kodirajo prikazani tarčni kót, in od moči inhibicije v lateralnih povezavah - ožji kot je razpon aktivacije, manj razpršeni bodo odgovori. Zaradi naključnih premikov aktivacije se namreč ob času odgovora lahko zgodi, da najmočnejša aktivacija ni v nevronih, ki kodirajo točen kót tarče, pač pa v katerih od sosednjih nevronov. Udeleženec zato poda odgovor, ki ni povsem natančen. $\mathrm{Na}$ natančnost kodiranja $\mathrm{v}$ delovnem spominu lahko tako sklepamo iz razpršenosti odgovorov, ki naj bi izhajala neposredno iz moči in specifičnosti spominske sledi v prefrontalnem korteksu.

Ključna lastnost modela, ki izhaja iz fizioloških ugotovitev, je dejstvo, da se podobna aktivnost kot ob prikazu tarčnega dražljaja vzpostavi tudi ob prikazu motečega dražljaja. Če je moteči dražljaj dokaj oddaljen od tarčnega dražljaja, se v celicah, ki ustrezajo položaju motečega dražljaja, sicer vzpostavi prehodna aktivnost, vendar vztraja le v času prikaza dražljaja, nato pa izzveni. Kadar pa je moteči dražljaj dovolj blizu tarčnemu dražljaju, lahko pride do zlitja aktivacij, ki vrh aktivacije premakne v smeri proti položaju motečega dražljaja. Pri tem naj bi širina vzorca aktivacije zaradi normalizacije preko inhibitornih lateralnih povezav ostala enaka. Odgovori so zato manj točni, saj so zamaknjeni proti položaju motečega dražljaja, natančnost v smislu razpršenosti odgovorov pa se ne spremeni.

Možno je, da so čustveni dražljaji še posebno potentna motnja. Že sama prisotnost čustvenega dražljaja lahko izboljša občutljivost zaznavanja, ta učinek pa je najbolj izrazit, kadar se tarča pojavi na mestu, kjer se je predhodno pojavil čustven dražljaj (Phelps, Ling in Carrasco, 2006). Ob prikazu čustvenega dražljaja bi lahko zaradi ojačitve zaznavnih informacij spominske celice dosegla močnejša aktivacija, kar bi lahko povečalo vpliv motnje.

Vsi navedeni mehanizmi vzdrževanja položaja se nanašajo na predstave z visoko ločljivostjo oz. shranjevanje informacij o natančnem položaju tarčnega dražljaja. Študije pa kažejo, da lahko poleg natančne prostorske predstave $\mathrm{v}$ nalogi delovnega spomina vzdržujemo in uporabljamo tudi posplošene prostorske kategorije (Huttenlocher, Hedges in Duncan, 1991). Prostorske informacije lahko namreč kategoriziramo v skladu z naučenimi kategorijami v dolgoročnem spominu, kar najpogosteje pomeni delitev v štiri kvadrante - zgoraj levo in desno ter spodaj levo in desno (Huttenlocher, Hedges, Corrigan in Crawford, 2004). Kadar je informacija, ki smo si jo zapomnili, nepopolna oz. nenatančna, podan odgovor odraža delno rekonstrukcijo na podlagi kategorij. Pri tem imajo močan vpliv najboljši predstavniki kategorije oz. prototipi. Vsi kóti, ki se nahajajo v kvadrantu, so predstavniki kvadranta, najboljši ali prototipni predstavnik pa je 45stopinjski kót kot najbolj središčen med njimi. V več študijah so odkrili, da prototipni 45-stopinjski kóti močno vplivajo na informacije v prostorskem delovnem spominu (Haun, Allen in Wedell, 2005; Huttenlocher idr., 1991, 2004). Odgovori udeležencev so namreč v povprečju premaknjeni stran od meja kategorij (90-stopinjskih kótov) in proti prototipnim 45-stopinjskim kótom.

V študiji smo želeli preveriti, ali prisotnost motečih dražljajev vpliva na prostorski delovni spomin in ali je ta vpliv moduliran z nasičenostjo dražljajev. Primerjali smo vpliv motečih dražljajev, ki izstopajo bodisi zaradi podobnosti tarčnim dražljajem bodisi zaradi negativne čustvene nasičenosti. Pri tem smo želeli preveriti vpliv tako na natančnost visoko ločljivih predstav kot tudi na (v študijah pogosto spregledan) vpliv prostorskih kategorij. Natančneje smo želeli opredeliti ne le obstoj, temveč tudi smer motečega vpliva (proti ali stran od motnje). Predpostavljali smo, da bodo tako podobni kot negativni dražljaji bolj moteči od nevtralnih dražljajev. Na podlagi nevrofizioloških ugotovitev in računskih modelov prostorskega delovnega spomina smo predpostavljali, da se ob prisotnosti motnje razpršenost odgovorov ne bo povečala, pričakovali pa smo usmerjene premike proti motečim dražljajem.

\section{Metoda}

\section{Udeleženci}

V eksperimentu je skupno sodelovalo 27 udeležencev, vendar smo dva izločili zaradi nepopolnih podatkov. V analizah smo tako upoštevali podatke 25 udeležencev (osem moških). Starostno smo zajeli obdobje zgodnje odraslosti, v razponu 19-31 let $(M=23,3, S D=3,0)$. Udeleženci so bili študenti psihologije, medicine in kognitivne znanosti, ki so $\mathrm{z}$ udeležbo opravili del obveznosti pri študiju $(n=5)$, in prostovoljci, ki so se odzvali na oglase na spletnih straneh, družabnih omrežjih in poštnih seznamih $(n=20)$. Omeniti velja, da so tudi med njimi prevladovali študenti različnih študijskih smeri drugih fakultet in univerz. Udeleženci so bili večinoma desnoročni ( $n=23)$, dva pa sta bila obojeročna. Vsi so imeli normalen oz. z očali ali lečami ustrezno popravljen vid. Igralno palico so upravljali s svojo dominantno roko (obojeročni z desno).

\section{Pripomočki}

Strojna in programska oprema. Naloga je tekla na Shuttle J3 5800 računalniku z Intel Core i7 procesorjem z 2,80 GHz in $2 \mathrm{~GB}$ RAM-a v sistemu Windows Vista Business 2007, Service Pack 2. Slike so bile prikazane na 30-palčnem Invivo 000047, 2010, easy patient display zaslonu $\mathrm{z}$ resolucijo $2560 \times 1600$ pikslov. 
Tabela 1. Povprečne lastnosti uporabljenih negativnih in nevtralnih slik

\begin{tabular}{|c|c|c|c|c|c|}
\hline \multirow[b]{2}{*}{ Lastnost slike } & \multicolumn{2}{|c|}{ Slike: $M(S D)$} & \multicolumn{3}{|c|}{$t$ test } \\
\hline & Negativne & Nevtralne & $t$ & $d f$ & $p$ \\
\hline Valenca & $2,27 \quad(0,65)$ & $5,58 \quad(0,30)$ & $-26,02$ & 43,7 & 0,000 \\
\hline Vzburljivost & $6,66 \quad(0,39)$ & $4,17 \quad(0,58)$ & 20,00 & 54,3 & 0,000 \\
\hline Svetlost & $113,79(29,63)$ & $113,69(25,51)$ & 0,01 & 60,7 & 0,989 \\
\hline Kontrast & $59,20 \quad(9,08)$ & $59,96 \quad(8,93)$ & $-0,34$ & 62,0 & 0,736 \\
\hline Prostorske frekvence & $2,97 \quad(0,26)$ & $2,99 \quad(0,25)$ & $-0,20$ & 62,0 & 0,839 \\
\hline
\end{tabular}

Pri odgovarjanju so udeleženci uporabljali igralno palico proizvajalca Hybridmojo, primerno za uporabo $\mathrm{v}$ magnetnoresonančnem tomografu.

Eksperimentalno nalogo smo pripravili s programom PsychoPy (Peirce, 2007), pripravo in določanje značilnosti uporabljenih slik smo izvedli v okolju MATLAB (MathWorks, 2012), izenačevanje skupin slik po relevantnih značilnostih ter statistično obdelavo vedenjskih podatkov pa $\mathrm{v}$ računskem okolju $\mathrm{R}$ ( $\mathrm{R}$ Core Team, 2014).

Slike. Uporabili smo čustveno nasičene slike iz treh preverjenih zbirk s standardiziranimi ocenami valence in vzburljivosti: mednarodne - IAPS (Lang, Bradley in Cuthbert, 2008), Nencki - NAPS (Marchewka, Zurawski, Jednorog in Grabowska, 2014) in ženevske - GAPED (Dan-Glauser in Scherer, 2011). Slike smo obrezali v okroglo obliko in pomanjšali na premer 200 pikslov. Izbrali smo dve skupini slik: negativne $\mathrm{z}$ nizko valenco in visoko vzburljivostjo ter nevtralne s povprečno valenco in povprečno oz. nizko vzburljivostjo (na 9-stopenjski lestvici). Skupaj smo uporabili 32 negativnih (valenca 1-4, vzburljivost 6-9) in 32 nevtralnih slik (valenca 5-6, vzburljivost 3-5). Na vseh slikah je bil prisoten človek (celo telo, obraz ali kak drug del telesa). Da osnovne značilnosti slik ne bi vplivale na dobljene rezultate, smo skupini negativnih in nevtralnih slik s pomočjo računalniškega algoritma izenačili glede na povprečno svetlost, kontrast in porazdelitev prostorskih frekvenc (Maljkovic in Martini, 2005; Olshausen, 2005). Povprečne lastnosti obeh vrst slik so prikazane v tabeli 1 .

Za izdelavo kontrolnih premešanih oz. brezvsebinskih slik smo na vseh izbranih slikah izvedli Fourierjevo analizo frekvenčnega spektra, nato pa naključno premešali matriko prostorske razporeditve frekvenc in ohranili originalni spekter moči. Z inverzno Fourierjevo transformacijo smo tako spremenjene matrike pretvorili nazaj v slike. Na ta način smo ustvarili premešane slike, pri katerih so ohranjene osnovne lastnosti slik (barva, svetlost, kontrast, prostorske frekvence), vsebine pa ni več mogoče razločiti (Jacques in Rossion, 2004; Rossion in Caharel, 2011; Sadr in Sinha, 2004).

Naloga prostorskega delovnega spomina. Nalogo prostorskega delovnega spomina smo oblikovali po zgledu podobnih paradigem $\mathrm{v}$ študijah primatov (Funahashi, 2006; Goldman-Rakic, 1990). Dražljaji se vedno prikazujejo na isti razdalji od središča zaslona, vendar na različnih kótih - na navidezni krožnici, ki udeležencem ni znana oz. prikazana. Tak prikaz dražljajev neposredno odraža, na kakšen način je prostor kodiran $\mathrm{v}$ prefrontalnem korteksu, skladno $\mathrm{z}$ ugotovitvami in predpostavkami nevrofizioloških raziskav (GoldmanRakic, 1990; 1995).

V osnovni obliki naloge (slika 1A) je na začetku poskusa na sredini zaslona prikazana fiksacijska točka (2 s), v katero udeleženci usmerijo pogled. Nato se na zaslonu pokaže okrogla tarčna slika $(2 \mathrm{~s}) \mathrm{s}$ premešano vsebino. Udeleženci jo pogledajo in si zapomnijo njen položaj. Ko slika izgine, vrnejo oči v sredino zaslona, kjer se zopet pojavi fiksacijska točka. V premoru (8 s), ki sledi, udeleženci v mislih vzdržujejo položaj prikazane slike (kar je na sliki 2 ponazorjeno z zeleno črto). Na koncu poskusa se na sredini zaslona pokaže siv krog, ki ima enak premer kot prej prikazana slika. Naloga udeležencev je, da ga s pomočjo igralne palice premaknejo na mesto, kjer se je prej pojavila tarčna slika, in ga tam zadržijo, dokler ne izgine (4 s). Zadnji položaj kroga se zabeleži kot odgovor. Ker udeleženci uporabljajo igralno palico, da natančno obnovijo položaj tarče, naloga omogoča zvezno zbiranje podatkov o natančnosti iz poskusa v poskus, kar je prednost pred nalogami odloženega odziva, ki za odgovarjanje uporabljajo ponoven prikaz pravega ali nepravega položaja, udeleženci pa morajo prepoznati, ali gre za pravi položaj in se odzivajo binarno z da ali ne.

Naloga z motnjo (slika 1B) je podobna osnovni obliki naloge $\mathrm{z}$ enakim prikazom fiksacijske točke in tarče ter enakim načinom odgovarjanja. Razlika je v tem, da se med premorom in vzdrževanjem položaja tarčne slike prikaže še ena okrogla slika na drugem položaju. Naloga udeležencev je, da jo pogledajo, vendar si jim ni treba zapomniti njenega položaja. Udeleženci torej že vnaprej vedo, da se bo slika pojavila in da za izvedbo naloge ni pomembna. Slika se tako pojavi kot "čista" motnja - v nalogi nima nobene vloge in je za njeno izvajanje moteča. $\mathrm{V}$ nalogo z motnjo smo vključili tri vrste motečih slik - premešane, nevtralne in negativne. Premešane slike so potencialno moteče, ker so najbolj podobne tarčnim slikam, negativne pa zaradi čustvene vsebine. Nevtralne slike smo vključili kot kontrolni pogoj.

Ker je študija potekala $v$ magnetni resonanci ${ }^{1}$, je bil med poskusi daljši zamik, v katerem je bilo na zaslonu

\footnotetext{
${ }^{1}$ Rezultati meritev z magnetno resonanco niso predmet obravnavanega raziskovalnega vprašanja, zato v nadaljevanju niso predstavljeni.
} 

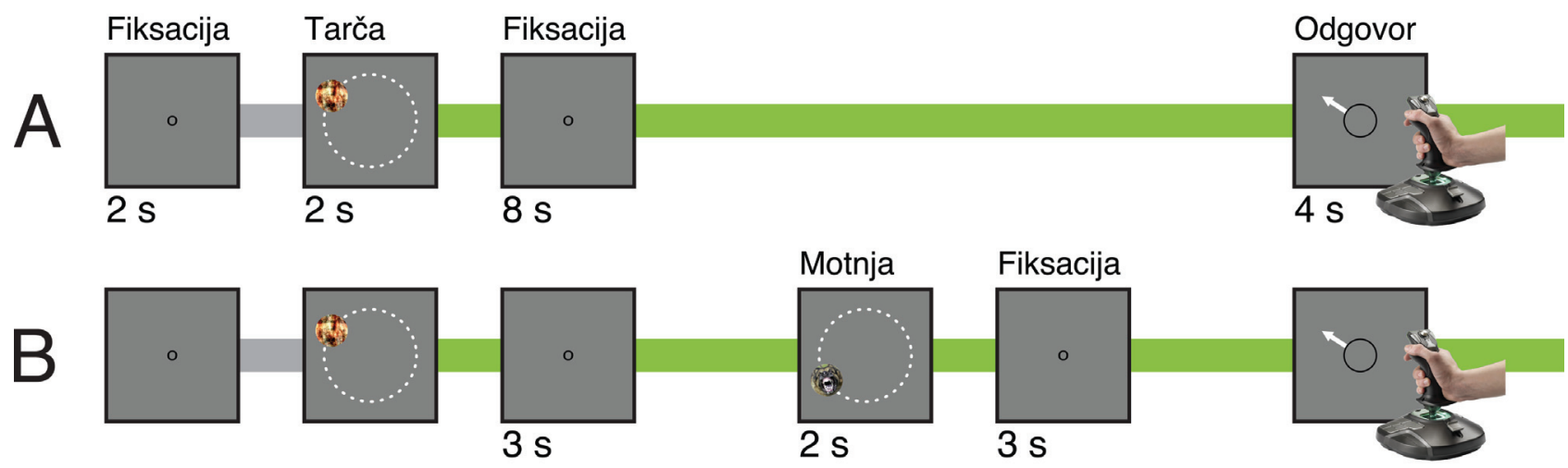

Slika 1. Potek naloge prostorskega delovnega spomina. A. Osnovna oblika naloge. Udeleženci si morajo zapomniti položaj okroglih premešanih slik (Tarča), ki so prikazane na različnih kótih na skriti krožnici (bele črte v poskusu niso prikazane), in ga po premoru obnoviti z igralno palico. B. Naloga z motnjo. V nalogi z motnjo je na sredini premora prikazana dodatna moteča slika (premešana, nevtralna ali negativna). Udeleženci jo morajo pogledati, ni pa si jim treba zapomniti njenega položaja. Na koncu poskusa obnovijo položaj prve, tarčne slike.

prikazano tripičje (...). Ponoven pojav fiksacijske točke je udeležence opozoril na začetek novega poskusa. Uporabili smo tri dolžine zamika: za vsakega od pogojev je bil v 15 poskusih zamik 12,5 sekund, v šest poskusih 15 sekund, v treh poskusih pa 17,5 sekund. Znotraj pogojev smo dolžine zamikov posameznim kombinacijam specifičnih slik, kótov in oddaljenosti dodatne slike pripisali naključno za vsakega udeleženca.

\section{Postopek}

Ob prihodu so udeleženci najprej prebrali in podpisali obveščeno soglasje za sodelovanje v raziskavi. Udeležence smo z vrstami nalog seznanili s pomočjo kratkih vaj pred testnim delom eksperimenta. Navodila so bila podana pisno na zaslonu, po potrebi so udeleženci lahko zastavili vprašanja in dobili dodatna ustna pojasnila. Udeleženci so opravili 6 poskusov osnovne oblike naloge in 6 poskusov naloge z motnjo (s po dvema slikama iz vsake kategorije).

Ker so udeleženci v nalogi za odgovarjanje uporabljali igralno palico, smo pred začetkom testnega dela opravili tudi motorično nalogo oz. vajo. $\mathrm{V}$ tej nalogi se po fiksaciji (2 s) hkrati prikažeta tarčna slika in sivi krog za odgovarjanje (4 s). Naloga udeležencev je, da s krogom čim bolj natančno prekrijejo tarčno sliko in ga zadržijo, dokler ne izgine. Ker je tarčna slika prisotna ves čas odgovarjanja, naloga ni spominska, temveč zahteva le fino motorično upravljanje $\mathrm{z}$ igralno palico. $\mathrm{Z}$ nalogo smo želeli pripraviti udeležence na nadaljnje naloge, $z$ njo so izvadili premikanje in natančno upravljanje igralne palice.

$\mathrm{V}$ testnem delu so vsi udeleženci najprej rešili dva bloka osnovne oblike naloge, tj. naloge A (po 16 poskusov na blok), nato pa štiri bloke naloge $\mathrm{z}$ motnjo, tj. naloge $\mathrm{B}$ (po 24 poskusov na blok). Poskuse osnovne oblike naloge in naloge $\mathrm{z}$ motnjo smo razdelili v ločene bloke, saj so pretekle študije pokazale, da lahko relativno redki poskusi brez motnje delujejo moteče - udeleženci pričakujejo prikaz dodatne slike, zato odsotnost prikaza negativno vpliva na točnost odgovorov (Anticevic idr., 2010). Skupno so udeleženci opravili šest blokov in 128 poskusov.

Slike so se vedno pojavljale na razdalji 400 pikslov od središča zaslona (na skriti krožnici), na 24 različnih kótih, enakomerno razporejenih po obodu krožnice (začenši s kótom $7,5^{\circ}, 22,5^{\circ}, 37,5^{\circ}$ itn. v intervalih po $15^{\circ}$ do $352,5^{\circ}$ ). Osem naključno izbranih kótov (po dva iz vsakega kvadranta) se je ponovilo dvakrat na pogoj, 16 pa enkrat (skupaj 32 poskusov).

V nalogi z motnjo smo položaj moteče slike določili relativno glede na položaj tarčne slike na šestih različnih oddaljenostih: $-40^{\circ},-35^{\circ},-30^{\circ}, 30^{\circ}, 35^{\circ}, 40^{\circ}$. Oddaljenosti smo izbrali tako, da sta bili tarčna in moteča slika dovolj blizu druga drugi, a se na razdalji 400 pikslov od središča zaslona pri premeru slike 200 pikslov nista prekrivali. Več različnih oddaljenosti smo izbrali zato, da bi se položaji motečih slik nekoliko razlikovali iz poskusa v poskus. Kateri kót prve slike bo v paru s katero od oddaljenosti, je bilo za vsakega udeleženca določeno navidezno naključno, tako da se je vsaka od oddaljenosti v vsakem kvadrantu pojavila po enkrat in da je vsak od pogojev vseboval enake kombinacije osnovnih kótov in oddaljenosti dodatne slike.

$\mathrm{V}$ celoti je študija $\mathrm{s}$ pripravami in snemanjem strukturnih ter mirovnih fMR slik trajala okoli 2 uri. Vedenjski eksperimentalni del je trajal okoli 1 ure.

\section{Statistične analize}

Kot odgovor v vsakem poskusu se je zabeležil položaj odgovornega kroga ob izginotju kroga ob koncu časa za odgovarjanje. Položaj je program zabeležil kot $x, y$ koordinati središča odgovornega kroga, iz katerih smo lahko izračunali različne mere oddaljenosti odgovora od položaja tarče. Na ta način smo zbrali zvezne podatke o natančnosti v vsakem poskusu. 
Kótna napaka. Natančnost $v$ nalogi delovnega spomina merimo $\mathrm{z}$ velikostjo napake - manjša kot je napaka, večjajenatančnost. Napako lahko najboljpreprosto opredelimo kot oddaljenost odgovora od položaja tarče. Formalno bi jo lahko izračunali kot evklidsko razdaljo med $x, y$ položajem tarče in $x, y$ položajem odgovora. Tak izračun $\mathrm{v}$ dvodimenzionalnem kartezijanskem koordinatnem sistemu upošteva tako premik v vodoravni kot navpični smeri oz. v polarnem koordinatnem sistemu tako kótno napako - premik bodisi v smeri urinega kazalca bodisi v nasprotni smeri urinega kazalca - kot tudi amplitudo - radialno oddaljenost od tarče v smeri proti izhodišču ali stran od njega. Ker pa amplituda $\mathrm{V}$ nalogi ostaja konstantna, je njena natančna obnova manj $\mathrm{v}$ domeni delovnega spomina - s ponavljanjem poskusov bi lahko prišlo do učenja (morda na povsem motorični ravni), kako daleč je potrebno premakniti ročico na igralni palici. Večjo razpršenost odgovorov in predvsem večjo vključenost delovnega spomina je mogoče pričakovati pri natančni obnovi kóta.

Temu primerno smo za osnovno mero napake uporabili kótno napako. Koordinate odgovora $\mathrm{v}$ kartezijanskem koordinatnem sistemu smo prekodirali $\mathrm{v}$ polarni koordinatni sistem in upoštevali le theto, torej kót odgovora, ne pa njegove amplitude (slika 2, Kotna napaka). Napako smo definirali kot vrednost razlike med kótom prikaza tarče in kótom odgovora. Negativne vrednosti kótne napake tako označujejo premik v smeri urinega kazalca, pozitivne pa premik v nasprotni smeri.

Predpostavljali smo, da je vkodiranje tarče dokaj natančno-aktivirajo se ustrezni nevroni, zaradi naključnih premikov aktivacije pa se včasih po naključju zgodijo premiki tako $\mathrm{v}$ smeri urinega kazalca kot $\mathrm{v}$ nasprotni smeri. Pričakovali smo, da glede na smer urinega kazalca $\mathrm{v}$ delovnem spominu ne obstaja nikakršna pristranskost in da bodo torej povprečne kótne napake blizu nič.

Povprečne kótne napake torej ne moremo uporabiti kot mere natančnosti, lahko pa na natančnost sklepamo iz razpršenosti odgovorov. Kadar je spominska sled močna in specifična (bolj natančna), je namreč razpršenost odgovorov manjša.

Napaka prototipa. Udeleženci pri reševanju naloge prostorskega delovnega spomina ne uporabljajo le mehanizmov, značilnih za natančno pomnjenje položaja, temveč tudi razne druge strategije in bližnjice, med katerimi je najpogostejša uporaba kvadrantov oz. prototipnih 45-stopinjskih kótov (Haun idr., 2005; Huttenlocher idr., 1991, 2004). Ker je delovni spomin nenatančen, smo pričakovali, da bo pri reprodukciji položaja prišlo do vpliva prototipa - odgovori bodo premaknjeni proti prototipu.

Za merjenje napake prototipa smo odgovore prekodirali tako, da so pozitivne vrednosti pomenile premik proti prototipu, negativne vrednosti pa odmik stran od prototipa (slika 2, Napaka prototipa). V nasprotju s povprečno kótno napako smo pričakovali, da bo povprečna napaka prototipa različna od nič in jo bomo lahko uporabili kot mero vpliva oz. strateške uporabe prostorskih kategorij.
Napaka motnje. Moteč dražljaj v nalogi prostorskega delovnega spomina vnese dodatno informacijo o položaju. Kot posledico vpliva motnje lahko pričakujemo usmerjen premik k motnji. Da bi formalizirali ta premik oz. napako, smo odgovore prekodirali tako, da so pozitivne vrednosti pomenile premik k motnji, negativne pa premik stran od motnje (slika 2, Napaka motnje). Ob izračunu povprečne napake motnje smo ponovno pričakovali, da bo vrednost različna od nič, v kolikor je motnja vplivala na odgovore.

Izločanje osamelcev. V študijah so nas zanimali predvsem tisti vplivi eksperimentalnih manipulacij, ki delujejo na vse poskuse $\mathrm{v}$ pogoju in se izražajo npr. kot spremembe $\mathrm{v}$ natančnosti delovnega spomina, razpršenosti, povprečni usmerjenosti rezultatov ipd. Da bi zagotovili, da rezultati res odražajo procese, ki so nas zanimali, smo iz podatkov pred izvedbo analiz izločili osamelce. Osamelce smo določali na podlagi več kriterijev.

Prvi kriterij je temeljil na oddaljenosti odgovora od položaja tarče. Občasno lahko med izvajanjem naloge pride do nepopolnega vkodiranja tarčnega položaja ali popolne izgube spomina za položaj. Možni razlogi so lahko nenadni padci pozornosti, motnje iz okolja, mežiki, prepočasen ali zgrešen motoričen odziv ipd. Pri takih poskusih pride do velikih napak - udeleženci povsem zgrešijo položaj tarče ali pa se sploh ne odzovejo. Kot zelo velike napake smo označili tiste odgovore, pri katerih je bila amplituda odgovora manj kot 200 pikslov (torej manj kot polovico poti do skrite krožnice, na kateri so se pojavljale tarčne slike) ali pri katerih je bila kótna napaka odgovora več kot $45^{\circ}$ (slika 3 , Oddaljenost). V takih poskusih so udeleženci bodisi zelo malo premaknili igralno palico bodisi zgrešili, v kateri četrtini zaslona se je pojavil tarčni dražljaj.

Drugi kriterij je prišel v poštev v nalogi z motnjo, kjer smo pričakovali, da bo dodatna slika vplivala na odgovore, bodisi privlačno bodisi odbojno. Položaj dodatnega dražljaja naj bi vplival na celotno porazdelitev odgovorov, ki se v povprečju izrazi kot usmerjen premik k položaju dodatnega dražljaja ali stran od njega. Dodatni dražljaj torej vpliva na spominsko sled, vendar le v manjši meri. Možno pa je, da v majhnem odstotku poskusov pride do velikih napak, ko dodatni dražljaj nadomesti ali povsem izbriše spominsko sled tarče. V tem primeru udeleženci zamenjajo, katerega od prikazanih položajev so morali obnoviti - položaj motečega dražljaja popolnoma nadomesti položaj tarče in udeleženci odgovorijo napačno.

Zamenjave lahko določimo na podlagi primerjave oddaljenosti odgovora od tarčnega dražljaja z oddaljenostjo od motnje. Ena možnost bi bila izločiti vse odgovore, ki so bližji položaju motnje kot položaju tarče. Vendar pa pri nekaterih poskusih, kjer so dodatni dražljaji precej blizu položaja tarče, in pri udeležencih, ki izkazujejo precejšnjo razpršenost v odgovorih, ta strategija sama po sebi ne daje zadovoljivih rezultatov, saj na ta način v oblaku odgovorov "odrežemo" marsikateri odgovor, ki glede na razdaljo od tarče ne odstopa bistveno od ostalih rezultatov. Zato 


\section{Kotna napaka}
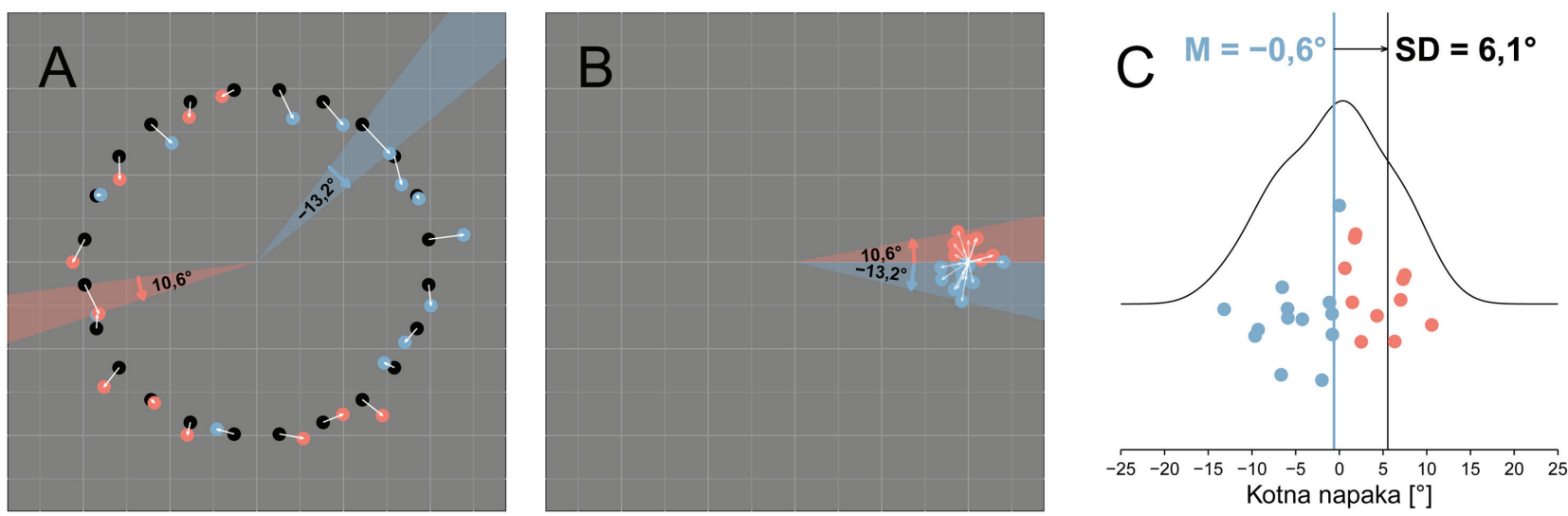

\section{Napaka prototipa}
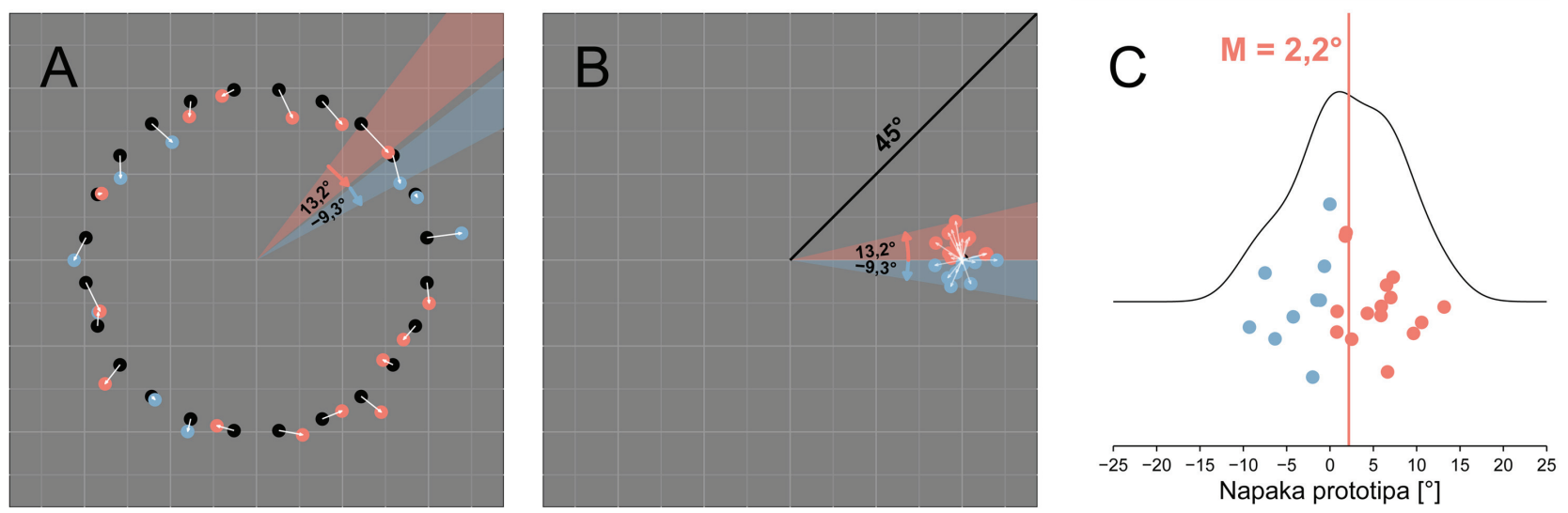

\section{Napaka motnje}
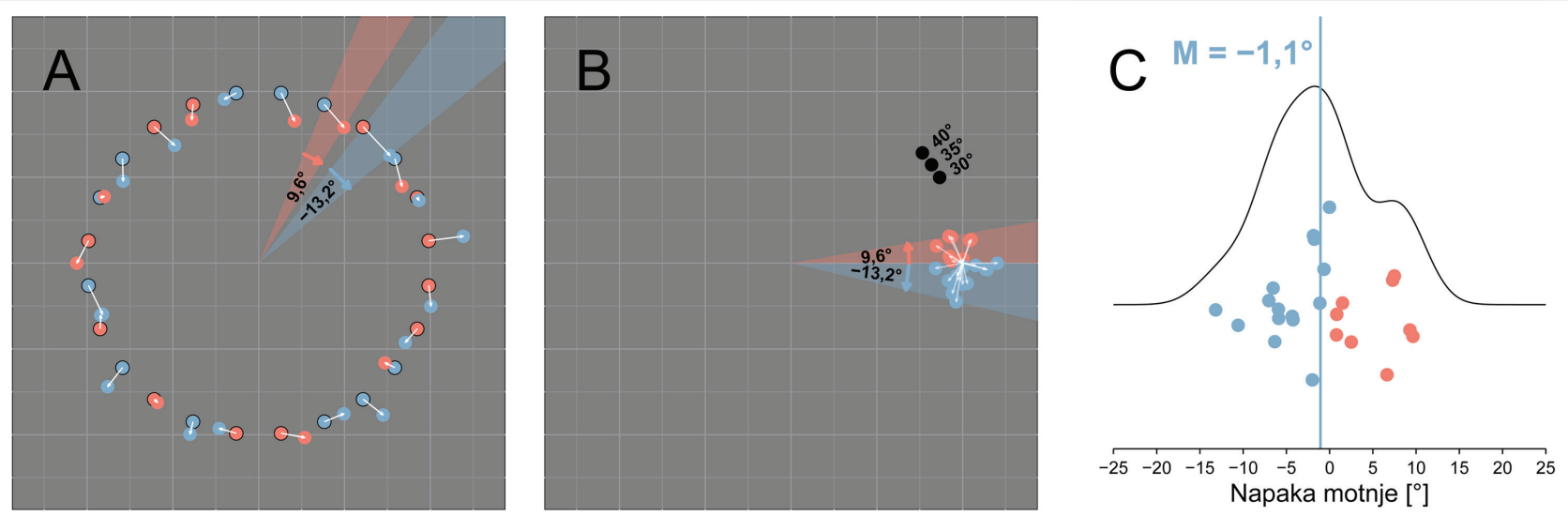

Slika 2. Mere natančnosti prostorskega delovnega spomina. Kótna napaka. A. Tarče in odgovori. Črne pike prikazujejo položaj 24 tarč v pogoju, barvne pike pa položaj odgovora. Tarčo s podanim odgovorom povezuje bela puščica.

Položaj odgovora prekodiramo v polarni koordinatni sistem in kot napako upoštevamo le kót med smerjo tarče in smerjo odgovora. Amplitudo odgovora - oddaljenost od središča zaslona - pri tem zanemarimo, saj je amplituda tarče tekom poskusov ostajala konstantna. Negativne vrednosti (modra) so pripisane odmikom v smeri urinega kazalca, pozitivne (rdeča) pa odmikom v nasprotni smeri urinega kazalca. Obarvana kóta prikazujeta minimalno in maksimalno kótno napako. $B$. Oblak odgovorov. Položaje odgovorov rotiramo tako, kot bi bile vse tarče prikazane na kótu $0^{\circ}$ oz. na položaju $x=400$ pikslov, $y=0$ pikslov. Na ta način je lepše razvidna razpršenost odgovorov okoli položaja tarče. C. Razpršenost kótne napake. Mero razpršenosti formaliziramo z izračunom povprečne kótne napake in njene standardne deviacije. V predstavljenem primeru je povprečna kótna napaka blizu nič (modra črta) - v odgovorih ni bistvene pristranskosti k podajanju odgovorov bodisi v smeri urinega kazalca bodisi v nasprotni smeri urinega kazalca. O natančnosti delovnega spomina nam več pove standardna deviacija odgovorov. Napaka prototipa. Udeleženci pri odgovarjanju upoštevajo informacijo o kvadrantu, v katerem se je nahajala tarča, in svoje odgovore premikajo k prototipu - tarči najbližjemu 45-stopinjskemu kótu. A. Tarče in odgovori. Odgovori so zdaj 
obarvani glede na napako prototipa - vrednosti kótne napake smo prekodirali tako, da pozitivne vrednosti označujejo premik k najbližjemu 45-stopinjskemu kótu, negativne vrednosti pa premik stran od njega. Obarvana kóta ponovno označujeta minimalno in maksimalno vrednost napake. Kljub temu, da sta oba premika v smeri urinega kazalca, pa je rdeč premik v smeri proti prototipu, moder pa v smeri stran od prototipa, zato imata različen predznak. B. Oblak odgovorov. Odgovore rotiramo tako, kot bi bile vse tarče prikazane na kótu $0^{\circ}$ in vsi najbližji 45-stopinjski kóti v desnem zgornjem kvadrantu, kjer je prototipni 45-stopinjski kót označen s črto. Oblak odgovorov je zdaj nekoliko drugačen - njegovo težišče je premaknjeno v smeri proti 45-stopinjskemu kótu. C. Povprečna napaka prototipa. Privlačen vpliv prototipa premakne povprečno napako prototipa v pozitivno smer (rdeča črta). Napaka motnje. Poleg vpliva prototipne vrednosti pričakujemo tudi vpliv motnje, ki se kaže kot usmerjen premik k ali stran od položaja moteče slike. A. Tarče in odgovori. Moteče slike so se pojavljale tako v smeri urinega kazalca kot v nasprotni smeri urinega kazalca glede na položaj tarče. Zaradi preglednosti položaji motečih slik niso prikazani, so pa tarče (pike s črno obrobo) obarvane glede na smer, kjer se je pojavila moteča slika (rdeče v nasprotni smeri urinega kazalca, modre pa v smeri urinega kazalca). Odgovori (pike brez obrobe) so obarvani glede na napako motnje - pozitivna vrednost (rdeča) označuje premik v smeri motnje, negativna vrednost (modra) pa premik v smeri stran od motnje. B. Oblak odgovorov. Odgovore rotiramo tako, kot bi bile vse tarče prikazane na kótu $0^{\circ}$ in vse moteče slike v nasprotni smeri urinega kazalca. Položaji motečih slik so prikazani s črno piko (na oddaljenosti $30^{\circ}, 35^{\circ}$ in $40^{\circ}$ ). C. Povprečna napaka motnje. V prikazanem primeru se težišče oblaka premakne stran od motnje, kar kaže na odbojni vpliv, ki povprečno napako motnje premakne v negativno smer (modra črta).
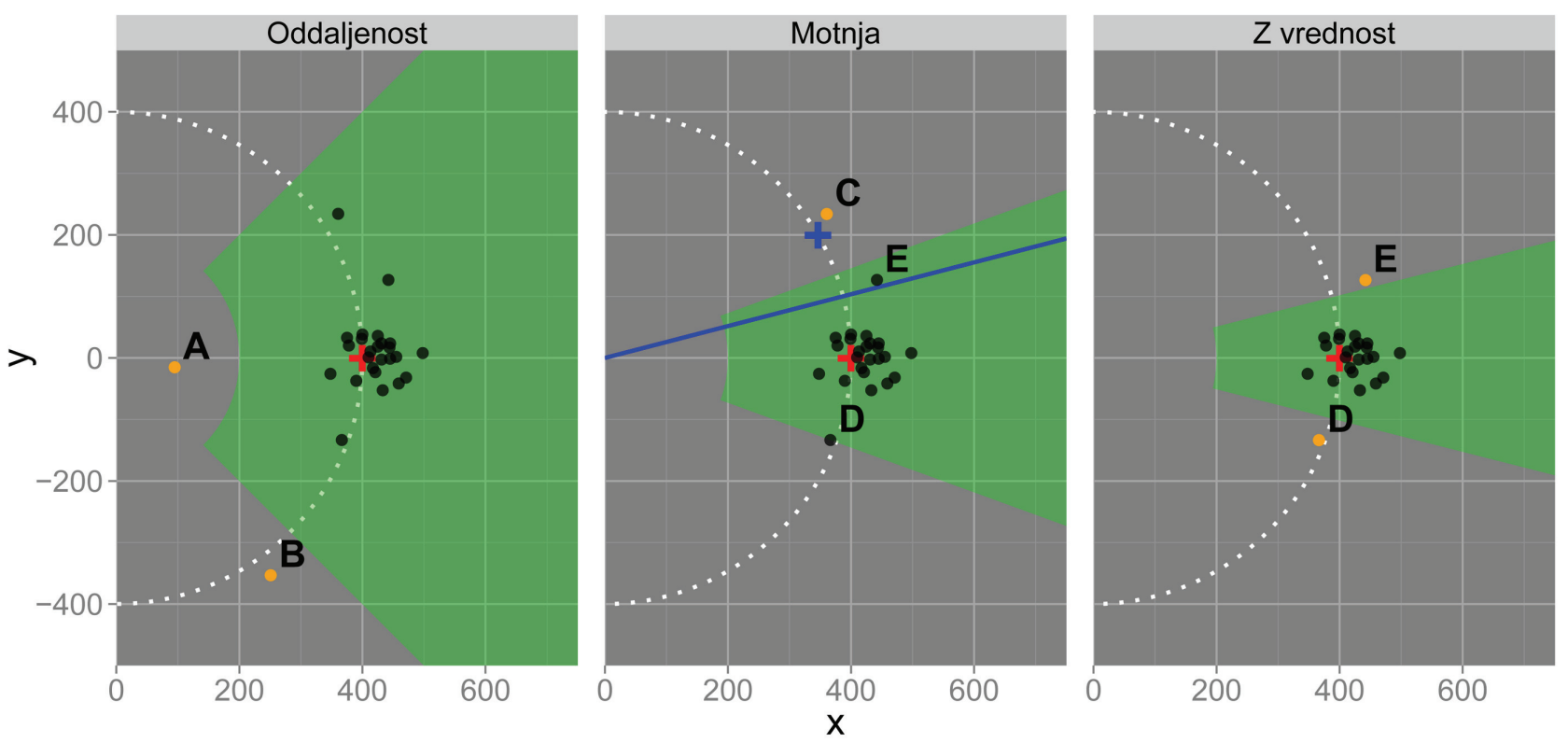

Slika 3. Kriteriji izločanja osamelcev. Slike prikazujejo primer rezultatov enega udeleženca v enem pogoju. Rezultati so rotirani tako, kot bi bile vse tarče prikazane na položaju $x=400$ pikslov, $y=0$ pikslov (rdeč križec), kar omogoča pregled porazdelitve odgovorov. Z belo črtkano črto je prikazana skrita krožnica, na kateri so se prikazovale tarče (prikazana je le desna polovica zaslona). Oddaljenost. Zeleno senčenje označuje območje, kjer je razdalja od izhodišča večja od polovice poti do krožnice ( $>200$ pikslov) in razdalja od tarče manjša od $45^{\circ}$. Točka A ne ustreza prvemu, točka B pa drugemu pogoju, zato ju izločimo iz nadaljnjih analiz. Motnja. Moder križec prikazuje položaj motnje (v primeru na oddaljenosti $30^{\circ}$ od tarčnega dražljaja). Vse točke nad modro črto so možni osamelci, saj so od motnje oddaljene manj kot od tarče. Pri izločanju upoštevamo tudi razpršenost odgovorov. Točka D je na skrajnem položaju oblaka odgovorov v smeri stran od motnje. To razdaljo upoštevamo tudi v smeri proti motnji, kar označuje zeleno območje. Točka C pade izven območja in je izločena kot osamelec. Točko E ohranimo, saj je kljub bližini motnji še znotraj območja maksimalne razpršenosti. Z-vrednost. Na podlagi preostalih točk izračunamo $z$-vrednosti kótne napake. Zeleno območje označuje vrednosti znotraj razdalje $3 S D$. Točki D in E izločimo na podlagi previsoke $z$ vrednosti.

smo pri izločanju zamenjav upoštevali tudi razpršenost rezultatov. Rezultate smo prekodirali tako, da je pozitivna razdalja odražala premik k motnji, negativna razdalja pa premik stran od motnje. Ker v nekaterih pogojih povprečje tako izračunane napake motnje ni bilo enako nič, smo izračunali povprečen premik, nato pa maksimalno razdaljo od povprečja v smeri stran od položaja motnje. To razdaljo smo uporabili kot maksimalno mejo razpršenosti znotraj posameznega pogoja. Na podlagi maksimalne razdalje smo izračunali, kakšen premik od povprečja proti motnji še spada $v$ enakovredno območje. Znotraj območja smo obdržali vse rezultate, zunaj njega pa smo odrezali le tiste rezultate, ki so hkrati ustrezali tudi pogoju, da so bližje motnji kot tarčnemu dražljaju (slika 3, Motnja). 


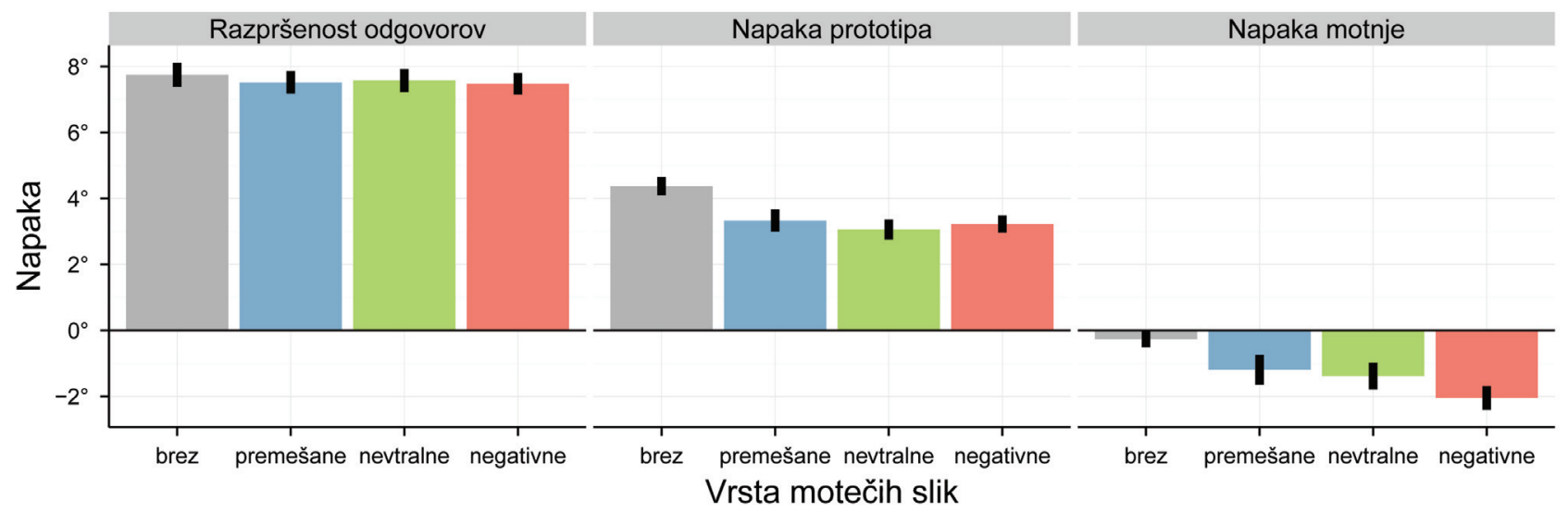

Slika 4. Povprečne napake. Razpršenost odgovorov. Odgovori udeležencev so variirali preko poskusov, vendar vrsta moteče slike ni vplivala na razpršenost odgovorov. Napaka prototipa. Odgovori udeležencev so bili v povprečju premaknjeni k najbližjemu 45-stopinjskemu kótu - prototipu kvadranta, v katerem se je nahajala tarča. Ob prisotnosti moteče slike se je ta premik zmanjšal, vendar med različnimi vrstami motečih slik ni bilo razlik. Napaka motnje. Ob prisotnosti moteče slike so udeleženci svoje odgovore v povprečju premaknili stran od položaja moteče slike. Učinek je bil najbolj izrazit pri negativnih slikah. Ročaji prikazujejo \pm eno standardno napako aritmetične sredine.

Slednjič smo na tako okleščenih podatkih izračunali $z$-vrednosti kótne napake za vsakega udeleženca za vsak pogoj in izločili tiste poskuse, kjer je absolutna $z$-vrednost presegla vrednost 3 (slika 3, Z-vrednost). S tem smo želeli $\mathrm{v}$ analizi ohraniti le najbolj stabilne rezultate.

$\mathrm{Na}$ podlagi premajhne oddaljenosti od izhodišča smo izločili $11(0,3 \%)$ poskusov, na podlagi prevelike oddaljenosti od tarče pa $10(0,3 \%)$ poskusov. Na podlagi primerjave med oddaljenostjo od tarče in motnje smo izločili $34(1,1 \%)$ poskusov, na podlagi $z$-vrednosti pa $20(0,6 \%)$. Skupaj smo na podlagi vseh kriterijev izločili $68(2,1 \%)$ poskusov oz. $0-5$ poskusov na udeleženca in pogoj. Pri tem pri večini udeležencev in pogojev nismo izločili nobenega $(n=52)$ ali pa le en ali dva poskusa $(n=$ 44). Udeleženci/pogoji z več napakami so izjeme $(n=4)$.

\section{Rezultati}

Izvedli smo analizo variance s ponovljenimi meritvami z enim dejavnikom (vrsta moteče slike) s štirimi ravnmi (brez moteče slike, premešane, nevtralne in negativne moteče slike). Kjer je analiza variance pokazala pomembne učinke motečih slik, smo analizo dopolnili Z načrtovanimi kontrasti. Načrtovani kontrasti so bili zastavljeni ortogonalno in primerjajo neodvisne deleže variance, zato nismo uporabili popravka $p$ vrednosti (Field, Miles in Field, 2012, pp. 865-992). V pogoju brez motnje moteča slika in posledično napaka motnje nista bili prisotni, zato primerjava vseh štirih pogojev ni bila smiselna. Pri napaki motnje smo tako izvedli analizo variance s tremi ravnmi dejavnika (premešane, nevtralne in negativne moteče slike) le v pogojih, kjer je bila prisotna motnja. Kot mero velikosti učinka pri analizi variance navajamo posplošeno eto kvadrat (Bakeman, 2005), pri $t$-testih pa Cohenov $d$ (Cohen, 2013).

\section{Razpršenost odgovorov}

Odgovori udeležencev so bili v povprečju usmerjeni v kótni položaj tarče. Pričakovano je bila povprečna kótna napaka blizu $0^{\circ}, M=-0,26^{\circ}, t(24)=-1,19, p=0,245$, $d=-0,34$. Razpršenost kótne napake (slika 4) kaže, da delovni spomin ni vedno povsem točen - opazno je drsenje spominske sledi, zaradi katerega udeleženci pri odgovarjanju delajo napake (tako v smeri urinega kazalca kot obratno). Med različnimi vrstami motečih slik ni bilo statistično pomembnih razlik v razpršenosti kótne napake, $F(3,72)=0,27, p=0,847, \eta^{2}=0,004$.

\section{Napaka prototipa}

Udeleženci so $\mathrm{v}$ svojih odgovorih uporabljali informacijo o kvadrantu, v katerem se je nahajala tarča, in svoje odgovore prilagajali glede na prototip kvadranta - kót $45^{\circ}$. Odgovori so bili v povprečju premaknjeni $\mathrm{k}$ najbližjemu 45-stopinjskemu kótu, $M=3,5^{\circ}, t(24)=$ 14,86, $p<0,001, d=0,99$ (slika 4). Med pogoji so bile statistično pomembne razlike, $F(3,72)=8,33, p<0,001$, $\eta^{2}=0,11$, vendar predvsem na račun pogoja brez moteče slike. Kadar je bila v nalogi prisotna moteča slika, je bila v primerjavi s pogojem brez moteče slike napaka prototipa zmanjšana, $\Delta=-1,17^{\circ}, t(72)=-4,91, p<0,001, d=-0,33$, med različnimi vrstami motečih slik pa ni bilo razlik, $F(2$, 48) $=0,444, p=0,644, \eta^{2}=0,01$.

\section{Napaka motnje}

Na odgovore udeležencev je vplivala tudi prisotnost motnje. Udeleženci so svoje odgovore umikali nekoliko stran od položaja moteče slike, torej na tisto stran tarče, kjer se ni pojavila moteča slika, $M=-1,54^{\circ}, t(24)=-4,33$, $p<0,001, d=-0,44$ (Slika 4). Moteče slike so se v tem 


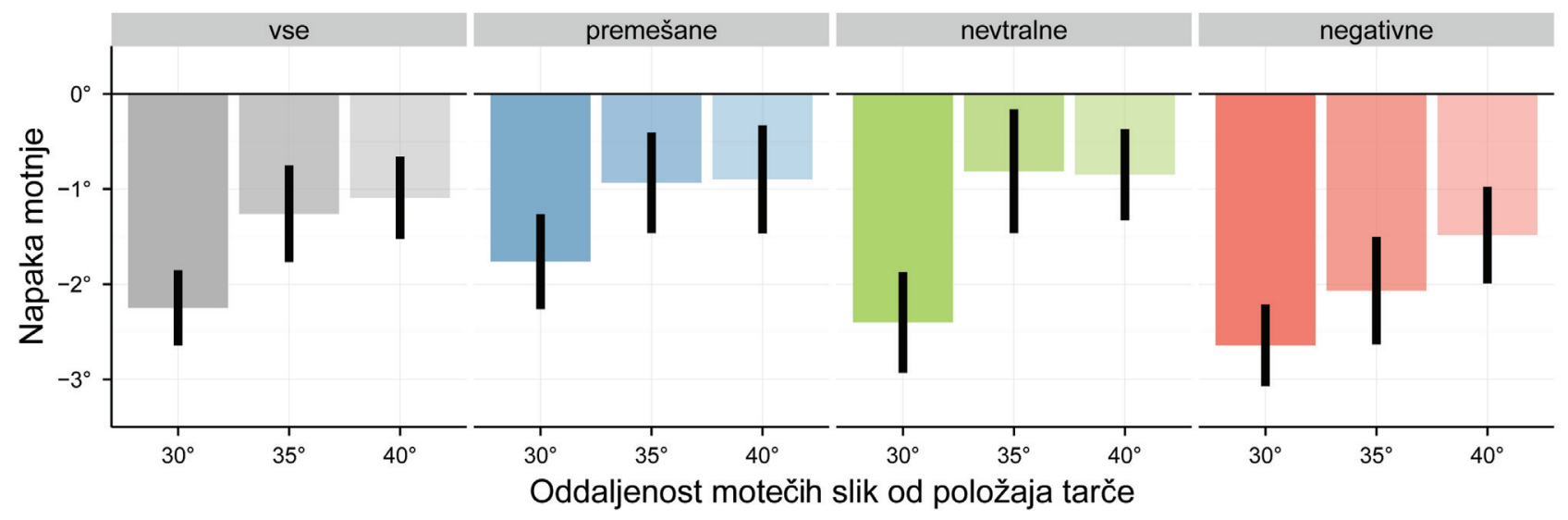

Slika 5. Vpliv oddaljenosti motečega dražljaja na napako motnje. Udeleženci se bolj umikajo od položaja motnje, kadar je moteč dražljaj prikazan blizu tarčnemu. Z večanjem oddaljenosti napaka motnje upade, še posebno pri premešanih in nevtralnih slikah, medtem ko se pri negativnih motečih slikah učinek ohrani v nekoliko večji meri tudi pri večjih oddaljenostih. Ročaji prikazujejo \pm eno standardno napako aritmetične sredine.

učinku razlikovale, $F(2,48)=3,50, p=0,038, \eta^{2}=0,03$, pri čemer je šla glavnina učinka na račun negativnih slik, $\Delta=-0,76^{\circ}, t(48)=-2,58, p=0,013, d=-0,21$ (kontrast s povprečjem premešanih in nevtralnih slik), medtem ko se vpliva premešanih in nevtralnih slik nista razlikovala, $\Delta$ $=-0,19^{\circ}, t(48)=-0,58, p=0,568, d=-0,06$.

Večina $(n=20)$ udeležencev je izkazovala negativno povprečje napake motnje, štirje so bili blizu ničle in le en udeleženec je izkazoval pozitivno povprečje oz. premik proti položaju motečega dražljaja.

Preverili smo tudi, kako na velikost napake motnje vpliva oddaljenost motečega dražljaja od položaja tarče. Preko vseh poskusov v nalogi, ne glede na vrsto motečega dražljaja (slika 5, razdelek vse), smo našli statistično pomemben učinek oddaljenosti, $F(2,48)=3,62, p=0,030$, $\eta^{2}=0,21$. Napaka motnje je bila večja, kadar so bili moteči dražljaji prikazani bližje tarčnemu dražljaju.

Opaziti je bilo mogoče tudi nekatere razlike glede na vrsto motečih dražljajev (slika 5) - pri negativnih dražljajih je bil na vseh oddaljenostih vpliv motečega dražljaja večji kot pri nevtralnih ali premešanih dražljajih. Učinek je bil še posebno opazen pri večjih oddaljenostih $\left(35^{\circ}\right.$ ali $\left.40^{\circ}\right)$, kjer je vpliv motnje pri nevtralnih in premešanih dražljajih upadel v večji meri kot pri negativnih dražljajih. Vendar pa interakcija med oddaljenostjo in vrsto motečega dražljaja ni bila statistično pomembna, $F(4,192)=0,49, p=0,740$, $\eta^{2}=0,006$.

\section{Razprava}

V študiji smo preverjali vpliv različnih motečih dražljajev na natančnost odgovorov v nalogi delovnega spomina za položaj. Natančnost smo opredelili na dva načina: kot splošno spremembo v razpršenosti odgovorov, ki kaže na manj specifično kodiranje položaja v delovnem spominu, in kot usmerjen premik stran ali $\mathrm{k}$ položaju motečega dražljaja. Preverili smo tudi morebitne vplive na pomnjenje in uporabo prostorskih kategorij.

\section{Moteči dražljaji ne povečajo razpršenosti odgovorov}

Rezultati niso kazali razlik v razpršenosti odgovorov. Ta se ob prisotnosti motečih dražljajev ni povečala, prav tako nismo našli razlik $\mathrm{v}$ razpršenosti glede na vrsto motečih dražljajev. Kaže torej, da prisotnost motečega dražljaja ne vpliva bistveno na specifičnost kodiranja položaja v delovnem spominu ali pa je vpliv zelo majhen in ga kljub večji občutljivosti merjenja, ki izhaja iz zveznega merjenja natančnosti, ni bilo mogoče statistično potrditi. Ta rezultat je skladen s predpostavko, da motnje ne spremenijo širine vzorca aktivacije oz. "ostrine" predstave položaja.

\section{Udeleženci pri reševanju uporabljajo prostorske kategorije}

Nasprotno smo $\mathrm{v}$ rezultatih zaznali kar nekaj usmerjenih premikov. Tako kot $\mathrm{v}$ predhodnih študijah (Haun idr., 2005; Huttenlocher idr., 1991, 2004), se je tudi v naši potrdilo, da udeleženci pri odgovarjanju uporabljajo informacijo o kvadrantu, v katerem se je prikazala tarča.

Uporabo kategorij je mogoče razlagati na več načinov. Pomnjenje natančnega položaja zahteva natančno vzdrževanje pozornosti na mestu, kjer se je pojavil tarčni dražljaj, kar zahteva precej kognitivnega napora, medtem ko je uporaba posplošenih kategorij bržkone enostavnejša. Udeleženci jih morda lahko namerno vzdržujejo $\mathrm{v}$ besednem delovnem spominu v obliki besednih oznak, kar so nekateri udeleženci tudi potrdili v pogovoru po končanem eksperimentu. S pomočjo kategorij lahko udeleženci rešujejo nalogo $\mathrm{z}$ manj truda, vendar pri omejenem številu možnih položajev tarče še vedno dokaj natančno.

Po drugi strani nekateri avtorji zagovarjajo pozitiven pomen kategorij (Haun idr., 2005; Huttenlocher idr., 1991, 2004) - kadar je predstava visoke ločljivosti manj natančna, lahko kategorije pripomorejo k natančnosti 
odgovorov, predvsem preko zmanjšanja razpršenosti rezultatov. Udeleženci bi lahko kategorije uporabljali strateško, kot dodatno pomoč v primeru, da se tekom poskusa izgubi natančna informacija o položaju. Odgovor je tako kombinacija natančne informacije o položaju (ki je lahko iz poskusa v poskus bolj ali manj zanesljiva) in kategorije, ki se preko poskusov izrazi kot premik proti prototipnim predstavnikom kategorij.

\section{Moteči dražljaji zmanjšajo vpliv prototipnih kótov}

Kadar so v nalogi prisotni moteči dražljaji, se napaka prototipa zmanjša, kar najverjetneje kaže na to, da kategorij udeleženci ne uporabljajo zgolj kot strategijo za lažji način reševanja naloge. Moteči dražljaji, še posebej negativni, vnesejo v nalogo dodaten stres in kognitivne zahteve. Če so kategorije lažji način reševanja naloge, bi pričakovali, da se ob prisotnosti motečih dražljajev udeleženci še bolj zanašajo na kategorično kodiranje in se vpliv prototipnih kótov še poveča. Nasprotno pa v rezultatih najdemo ravno obraten učinek - ob prisotnosti motečih dražljajev, ne glede na njihovo vrsto, se učinek prototipov zmanjša. Možna razlaga je, da udeleženci kategorije uporabljajo zavestno in strateško, zato imajo ob prisotnosti motečih dražljajev tudi za to strategijo na voljo manj virov.

Druga možnost je, da se kategorije registrirajo in vplivajo na odgovore dokaj avtomatično, brez posebnega truda ali zavestne volje udeležencev, in delujejo na podoben način kot moteči dražljaji. Prototipni kóti izstopajo v zaznavi prostora kot najboljši predstavniki kategorij in se morda $\mathrm{v}$ prostorskem zemljevidu registrirajo $\mathrm{v}$ obliki povečane aktivacije, ki lahko vpliva na spominske predstave (Jerde in Curtis, 2013). V tem primeru bi ob prisotnosti drugih motečih dražljajev pričakovali, da se vpliv prototipov zmanjša. V študijah vidnega iskanja se je namreč izkazalo, da zaznavna obremenjenost (dodatni moteči dražljaji) zmanjša distraktibilnost, medtem ko izvršilna obremenjenost (dodatna naloga) distraktibilnost poveča (Lavie, 2005). Po tej razlagi bi sicer pričakovali večji učinek prototipa pri negativnih dražljajih, saj naj bi ti bolj obremenili izvršilne vire. Numerično je bila v naši raziskavi razlika pri izstopajočih dražljajih (tako podobnih kot negativnih) sicer nekoliko večja kot pri nevtralnih, vendar ni bila statistično pomembna.

\section{Moteči dražljaji imajo odbojen vpliv na odgovore}

Poleg usmerjenega premika proti položaju prototipa najdemo $\mathrm{v}$ rezultatih tudi usmerjen premik stran od motečega dražljaja. Rezultat je presenetljiv, saj bi na podlagi nevrofizioloških ugotovitev in računskih modelov pričakovali premik proti motečemu dražljaju. V procesu zaznave motečega dražljaja se namreč aktivirajo tudi prefrontalne nevronske mreže, ki shranjujejo položaj (Funahashi, 2013). Kadar je moteči dražljaj dovolj blizu tarčnemu, računski modeli predpostavljajo zlitje aktivacij, ki naj bi vrh aktivacije in posledično odgovor premaknil proti položaju motečega dražljaja (Compte, 2000; Murray idr., 2012).

Računski modeli torej predvidevajo, da se natančen položaj motečega dražljaja registrira kot vidni vhod v celicah prefrontalnega in parietalnega korteksa, ki položaj kodirajo zvezno. Možno pa je, da se moteči dražljaj registrira tudi kategorično - udeleženci vedo, da se na tem mestu tarča ni prikazala, kar morda lahko pojasni, zakaj pride do odbojnega vpliva. Udeleženci bi lahko na podlagi položaja »ne-tarče« ustrezno prilagodili oz. obtežili svoje odgovore, podobno kot se zgodi pri upoštevanju prototipnih kótov. Za razliko od prototipnih kótov pa se položaj motečega dražljaja spreminja iz poskusa v poskus. Udeleženci lahko položaj motnje pri odgovarjanju uporabijo le, če si na nek način zapomnijo, kje se je motnja pojavila. Za to pa verjetno najlažje uporabijo enake mehanizme kot za zapomnitev tarče.

Za pomnjenje motečih dražljajev lahko ponovno najdemo dve razlagi. Možno je, da udeleženci neučinkovito filtrirajo moteče dražljaje (Vogel, McCollough in Machizawa, 2005), ki se zato registrirajo in vzdržujejo v prefrontalnih celicah. Računski modeli delovnega spomina običajno modelirajo le vzdrževanje enega dražljaja (Compte, 2000), iz vedenjskih rezultatov pa je znano, da so ljudje sposobni hkratnega vzdrževanja več različnih položajev (Luck in Vogel, 1997). Ena redkih nevrofizioloških študij, ki je vključevala hkratno vzdrževanje položaja več tarč, je razkrila, da prihaja $\mathrm{v}$ tem primeru $\mathrm{v}$ prefrontalnih nevronih do povprečenja aktivnosti - ohranita se oba vrha aktivacije, področje med njima pa je zaradi prispevka obeh tarč bolj aktivirano kot v primeru, ko je prikazana le ena tarča (Matsushima in Tanaka, 2014). V vedenjskih rezultatih je bilo tako bolj verjetno, da je opica zmotno izbrala položaj med obema tarčama, kar bi se v zveznih podatkih najverjetneje kazalo kot premik odgovorov $\mathrm{k}$ dodatni tarči.

Podobno bi ob pomnjenju dodatnega dražljaja, ki je v našem primeru sicer moteč in ne tarčen, lahko pričakovali aktivacijo $\mathrm{z}$ dvema vrhovoma in premik odgovorov $\mathrm{k}$ motečemu dražljaju. Upoštevati pa je potrebno, da je bila študija Matsushime in Tanake (2014) izvedena na opicah in da je bil razmik med dvema tarčnima dražljajema vedno $90^{\circ}$. Možno je, da je za sočasno vzdrževanje dveh bolj podobnih položajev potreben dodaten mehanizem, ki predstavi ohranja ločeni. To bi zahtevalo dodatno inhibicijo, ki vzpostavi prostor za kodiranje novega položaja. Taka inhibicija bi predstavi odrivala narazen, kar bi lahko bil razlog za pojav odbojnih učinkov. V kolikor ta razlaga drži, bi pričakovali, da z razdaljo od tarče odbojni vpliv motnje upada, kar potrjujejo tudi naši rezultati.

Druga možnost je, da položaj motnje udeleženci uporabljajo strateško. Na tem položaju se zagotovo ni pojavila tarča, zato je možno, da udeleženci ta položaj namenoma inhibirajo. Vnos dodatne inhibicije bi vrh vzorca aktivacije $\mathrm{v}$ prefrontalnih nevronih ponovno odrinil stran od položaja motnje, še posebno, če se motnja nahaja blizu tarčnega položaja. 


\section{Negativni moteči dražljaji so bolj odbijajoči kot nevtralni}

Negativni dražljaji povzročijo $\mathrm{V}$ primerjavi $\mathrm{z}$ nevtralnimi in premešanimi večjo napako motnje. Možna razlaga je dodatna obremenjenost izvršilnih virov ob soočanju $\mathrm{z}$ vsebino slik, ki vodi $\mathrm{v}$ večje upoštevanje motečega položaja (Lavie, 2005). Po drugi strani pa se negativni dražljaji tudi zaznavno močneje registrirajo (Phelps idr., 2006), kar bi lahko povečalo stopnjo vhodne aktivacije ob zaznavi motečega dražljaja. Ob neuspešnem filtriranju in posledičnem pomnjenju obeh položajev bi bila za ohranjanje ločenosti obeh predstav potrebna močnejša inhibicija, ki bi povzročila večji odbojni vpliv. Podoben učinek bi sicer pričakovali tudi, če bi udeleženci namerno inhibirali položaj motečega dražljaja. Povečana vhodna aktivacija bi zahtevala večjo stopnjo inhibicije in bolj odrinila spominsko predstavo tarče. Zgolj na podlagi naših rezultatov med tema dvema razlagama ne moremo ločiti.

Močnejša vhodna aktivacija bi lahko vplivala tudi na "okno" vpliva motečih dražljajev. Predpostavljamo namreč, da imajo ti vpliv le, če so dovolj blizu glavni aktivaciji. Če je aktivacija negativnih motečih dražljajev močnejša, je za ločenost aktivacij potrebna večja razdalja, kar pomeni, da na tarčno spominsko sled vplivajo tudi bolj oddaljeni dražljaji. Deloma se je to nakazalo tudi v naših rezultatih, saj se je vpliv negativnih motečih dražljajev v primerjavi z nevtralnimi in premešanimi slikami v večji meri ohranil tudi na večjih oddaljenostih, vendar razlike niso bile statistično pomembne.

\section{Pomanjkljivosti in predlogi za nadaljnje študije}

V študiji smo odkrili odbojne učinke motečih dražljajev, kijih trenutni računski modeli ne predvidevajo. Kot možno razlago smo izpeljali vnos dodatne inhibicije $\mathrm{v}$ vzorec aktivacije, ki bi lahko izhajal bodisi iz namerne potlačitve položaja motečega dražljaja bodisi iz pomanjkljivega filtriranja in pomnjenja dveh položajev. Precejšnja pomanjkljivost trenutnih računskih modelov prostorskega spomina je v tem, da ne razlagajo in modelirajo hkratnega pomnjenja več dražljajev. Na tem področju so bili sicer že narejeni prvi koraki, vendar izsledki prav tako nakazujejo privlačne in ne odbojnih vplivov (Matsushima in Tanaka, 2014). Ker pa je študij na tem področju še malo in ker je navedena študija uporabila precej različne tarčne dražljaje (ločene za $90^{\circ}$ ), je možno, da ob pomnjenju bolj podobnih položajev pride do drugačnih, odbojnih učinkov. Tovrstne interakcije bi bilo potrebno preveriti in modelirati.

Zgolj na podlagi trenutnih rezultatov tudi ne moremo ločiti med dvema razlagama - da je inhibicija, za katero predvidevamo, da jo sprožijo moteči dražljaji, posledica bodisi aktivne inhibicije $\mathrm{s}$ strani udeležencev bodisi mehanizma, ki je del sistema, ki v prefrontalnih nevronskih mrežah omogoča kodiranje podobnih položajev. Dodatne sklepe bi lahko izpeljali s pomočjo študije, v kateri bi primerjali učinke namernega pomnjenja dveh tarč z učinki motečih dražljajev. Če je inhibicija posledica pomnjenja, bodisi namernega bodisi nenamernega, bi pričakovali podobne odbojne učinke tako $\mathrm{v}$ primeru predvajanja druge tarče kot v primeru predvajanja motečih dražljajev. Če pa je inhibicija posledica namerne potlačitve položaja motečega dražljaja, bi odbojne učinke pričakovali le pri predvajanju motečih dražljajev, ne pa tudi pri predvajanju druge tarče.

Zaključke do neke mere otežuje tudi sočasen obstoj več usmerjenih vplivov - v naši študiji smo pokazali obstoj privlačnih vplivov prototipov in odbojnih vplivov motnje. V kolikor se ti učinki zgolj seštevajo, lahko z izračunom napake prototipa in motnje vseeno ločeno ocenimo vpliv obeh. V kolikor pa prihaja med obema vplivoma do interakcij, na ta način njunega vpliva ne moremo povsem razdvojiti. Zaradi omejitve trajanja eksperimenta $v$ naši študiji nismo mogli preveriti vseh možnih kombinacij oddaljenosti prototipa in oddaljenosti motnje. Prihodnje študije bi lahko uporabile več možnih kombinacij in natančneje opredelile morebitne interakcije med vplivom prototipov in vplivom motečih dražljajev, kar bi morda tudi dodatno osvetlilo, na kakšen način delujejo prototipi - ali gre za namerno pomnjenje kategorij ali morda le za nenamerno zaznavanje izstopajočih značilnosti prostora.

Dodatne informacije o vplivu različnih vrst motečih dražljajev bi prinesla tudi bolj natančna študija interakcij med čustveno nasičenostjo dražljajev in oddaljenostjo položaja motečega dražljaja od položaja tarče. V naših rezultatih se je nakazalo, da bi moteči dražljaji lahko imeli večji vpliv tudi na večjih oddaljenostih, vendar razlike niso bile statistično pomembne, zato bi bilo potrebno morebitni učinek razdalje preveriti v dodatnih študijah.

\section{Zaključki}

V študiji smo naslovili vprašanje vpliva različnih motenj na predstave $\mathrm{v}$ prostorskem delovnem spominu. Rezultati so pokazali, da motnje ne spremenijo specifičnosti (“ostrine") predstave tarčne lokacije v prostorskem delovnem spominu, vodijo pa do njenega premika. V nasprotju s pričakovanji moteči dražljaji niso delovali privlačno, temveč odbojno. Predpostavljamo dva možna mehanizma odmika. Prva možnost izhaja iz namerne potlačitve položaja motečega dražljaja, ki se izraža kot aktivna inhibicija živčnih celic, ki kodirajo položaj motnje. Druga možnost je, da udeleženci motnje ne filtrirajo učinkovito, temveč spontano beležijo položaja obeh dražljajev, tako tarčnega kot motečega. Predpostavljamo, da bi lahko stabilno vzdrževanje dveh ločenih bližnjih reprezentacij prav tako zahtevalo inhibicijo živčnih celic, ki kodirajo prostor med njima. V obeh primerih bi inhibicija vodila do premika aktivacije stran od položaja motečega dražljaja. Razločitev med obema možnostma zahteva nadaljnje vedenjske, fiziološke in računske študije. 


\section{Literatura}

Anticevic, A., Repovš, G. in Barch, D. M. (2010). Resisting emotional interference: brain regions facilitating working memory performance during negative distraction. Cognitive, Affective and Behavioral Neuroscience, 10(2), 159-173.

Awh, E. in Jonides, J. (2001). Overlapping mechanisms of attention and spatial working memory. Trends in Cognitive Sciences, 5(3), 119-126.

Awh, E., Vogel, E. K. in Oh, S.-H. (2006). Interactions between attention and working memory. Neuroscience, 139(1), 201-208.

Bakeman, R. (2005). Recommended effect size statistics for repeated measures designs. Behavior Research Methods, 37(3), 379-384.

Chafee, M. V. in Goldman-Rakic, P. S. (1998). Matching patterns of activity in primate prefrontal area $8 \mathrm{a}$ and parietal area 7ip neurons during a spatial working memory task. Journal of Neurophysiology, 79(6), 2919-2940.

Cohen, J. (2013). Statistical power analysis for the behavioral sciences. London, Združeno kraljestvo: Routledge.

Compte, A. (2000). Synaptic mechanisms and network dynamics underlying spatial working memory in a cortical network Mmodel. Cerebral Cortex, 10(9), 910-923.

Corbetta, M., Kincade, J. M. in Shulman, G. L. (2002). Neural systems for visual orienting and their relationships to spatial working memory. Journal of Cognitive Neuroscience, 14(3), 508-523.

Dan-Glauser, E. S. in Scherer, K. R. (2011). The Geneva affective picture database (GAPED): a new 730picture database focusing on valence and normative significance. Behavior Research Methods, 43(2), 468-477.

Dolcos, F. in McCarthy, G. (2006). Brain systems mediating cognitive interference by emotional distraction. The Journal of Neuroscience, 26(7), 2072-2079.

Dolcos, F., Diaz-Granados, P., Wang, L. in McCarthy, G. (2008). Opposing influences of emotional and nonemotional distracters upon sustained prefrontal cortex activity during a delayed-response working memory task. Neuropsychologia, 46(1), 326-335.

Dolcos, F., Kragel, P., Wang, L. in McCarthy, G. (2006). Role of the inferior frontal cortex in coping with distracting emotions. Neuroreport, 17(15), 1591-1594.

Fales, C. L., Becerril, K. E., Luking, K. R. in Barch, D. M. (2010). Emotional-stimulus processing in trait anxiety is modulated by stimulus valence during neuroimaging of a working-memory task. Cognition and Emotion, 24(2), 200-222.

Field, A., Miles, J. in Field, Z. (2012). Discovering statistics using $R$. London: Sage.

Funahashi, S. (2006). Prefrontal cortex and working memory processes. Neuroscience, 139(1), 251-261.
Funahashi, S. (2013). Space representation in the prefrontal cortex. Progress in Neurobiology, 103, 131-155.

Funahashi, S., Bruce, C. J. in Goldman-Rakic, P. S. (1989). Mnemonic coding of visual space in the monkey's dorsolateral prefrontal cortex. Journal of Neurophysiology, 61(2), 331-349.

Funahashi, S., Bruce, C. J. in Goldman-Rakic, P. S. (1990). Visuospatial coding in primate prefrontal neurons revealed by oculomotor paradigms. Journal of Neurophysiology, 63(4), 814-831.

Goldman-Rakic, P. S. (1990). Cellular and circuit basis of working memory in prefrontal cortex of nonhuman primates. Progress in Brain Research, 85, 325-335; discussion 335-336.

Goldman-Rakic, P. S. (1995). Cellular basis of working memory. Neuron, 14(3), 477-485.

Goldman-Rakic, P. S. (1999). The physiological approach: Functional architecture of working memory and disordered cognition in schizophrenia. Biological Psychiatry, 46(5), 650-661.

González-Garrido, A. A., López-Franco, A. L., GómezVelázquez, F. R., Ramos-Loyo, J. in Sequeira, H. (2015). Emotional content of stimuli improves visuospatial working memory. Neuroscience Letters, 585, 43-47.

Gruber, J., Purcell, A. L., Perna, M. J. in Mikels, J. A. (2013). Letting go of the bad: Deficit in maintaining negative, but not positive, emotion in bipolar disorder. Emotion, 13(1), 168-175.

Haun, D. B. M., Allen, G. L. in Wedell, D. H. (2005). Bias in spatial memory: A categorical endorsement. Acta Psychologica, 118(1-2), 149-170.

Huttenlocher, J., Hedges, L. V. in Duncan, S. (1991). Categories and particulars: Prototype effects in estimating spatial location. Psychological Review, 98(3), 352-376.

Huttenlocher, J., Hedges, L. V., Corrigan, B. in Crawford, L. E. (2004). Spatial categories and the estimation of location. Cognition, 93(2), 75-97.

Jacques, C. in Rossion, B. (2004). Concurrent processing reveals competition between visual representations of faces. Neuroreport, 15(15), 2417-2421.

Jerde, T. A. in Curtis, C. E. (2013). Maps of space in human frontoparietal cortex. Journal of Physiology, Paris, 107(6), 510-516.

Joormann, J., Levens, S. M. in Gotlib, I. H. (2011). Sticky thoughts: Depression and rumination are associated with difficulties manipulating emotional material in working memory. Psychological Science, 22(8), 979-983.

Kensinger, E. A. in Corkin, S. (2003). Effect of negative emotional content on working memory and long-term memory. Emotion, 3(4), 378-393.

Krause-Utz, A., Oei, N. Y. L., Niedtfeld, I., Bohus, M., Spinhoven, P., Schmahl, C. in Elzinga, B. M. (2012). Influence of emotional distraction on working memory performance in borderline personality disorder. Psychological Medicine, 42(10), 2181-2192. 
Lang, P. J., Bradley, M. M. in Cuthbert, B. N. (2008). International affective picture system (IAPS): Affective ratings of pictures and instruction manual (Technical Report a-8). Gainesville, FL, ZDA: University of Florida, NIMH Center for the Study of Emotion and Attention.

Lavie, N. (2005). Distracted and confused? Selective attention under load. Trends in Cognitive Sciences, 9(2), 75-82.

Lavric, A., Rippon, G. in Gray, J. R. (2003). Threatevoked anxiety disrupts spatial working memory performance: An attentional account. Cognitive Therapy and Research, 27(5), 489-504.

Li, X., Chan, R. C. in Luo, Y.-J. (2010). Stage effects of negative emotion on spatial and verbal working memory. BMC Neuroscience, 11, 60.

Luck, S. J. in Vogel, E. K. (1997). The capacity of visual working memory for features and conjunctions. Nature, 390(6657), 279-281.

Maljkovic, V. in Martini, P. (2005). Short-term memory for scenes with affective content. Journal of Vision, 5(3), 215-229.

Marchewka, A., Zurawski, Ł., Jednorog, K. in Grabowska, A. (2014). The Nencki Affective Picture System (NAPS): Introduction to a novel, standardized, wide-range, high-quality, realistic picture database. Behavior Research Methods, 46(2), 596-610.

MathWorks. (2012). MATLAB 2012b [računalniški program]. Natick, MA, ZDA: Avtor.

Matsushima, A. in Tanaka, M. (2014). Different neuronal computations of spatial working memory for multiple locations within versus across visual hemifields. The Journal of Neuroscience: the Official Journal of the Society for Neuroscience, 34(16), 5621-5626.

Murray, J. D., Anticevic, A., Gancsos, M., Ichinose, M., Corlett, P. R., Krystal, J. H. in Wang, X.-J. (2012). Linking microcircuit dysfunction to cognitive impairment: Effects of disinhibition associated with schizophrenia in a cortical working memory model. Cerebral Cortex, 24(4), 859-872.

Olshausen, B. (2005). Lab \#2. Topics in Vision [spletno učno gradivo]. Dosegljivo na: http://redwood.berkeley. edu/bruno/npb261b/lab2/lab2.html

Peirce, J. W. (2007). PsychoPy--Psychophysics software in Python. Journal of Neuroscience Methods, 162(12), 8-13.

Pessoa, L. (2009). How do emotion and motivation direct executive control? Trends in Cognitive Sciences, 13(4), 160-166.

Phelps, E. A., Ling, S. in Carrasco, M. (2006). Emotion facilitates perception and potentiates the perceptual benefits of attention. Psychological Science, 17(4), 292-299.

R Core Team. (2014). R: A language and environment for statistical computing [računalniški program]. Vienna, Austria: R Foundation for Statistical Computing. Dosegljivo na: URL http://www.R-project.org/.
Repovš, G. in Baddeley, A. D. (2006). The multicomponent model of working memory: explorations in experimental cognitive psychology. Neuroscience, 139(1), 5-21.

Rossion, B. in Caharel, S. (2011). ERP evidence for the speed of face categorization in the human brain: Disentangling the contribution of low-level visual cues from face perception. Vision Research, 51(12), 1297-1311.

Sadr, J. in Sinha, P. (2004). Object recognition and random image structure evolution. Cognitive Science, 28(2), 259-287.

Shackman, A. J., Sarinopoulos, I., Maxwell, J. S., Pizzagalli, D. A., Lavric, A. in Davidson, R. J. (2006). Anxiety selectively disrupts visuospatial working memory. Emotion, 6(1), 40-61.

Vogel, E. K., McCollough, A. W. in Machizawa, M. G. (2005). Neural measures reveal individual differences in controlling access to working memory. Nature, 438(7067), 500-503.

Zhang, J.-N., Xiong, K.-L., Qiu, M.-G., Zhang, Y., Xie, B., Wang, J., ... Zhang, J. J. (2013). Negative emotional distraction on neural circuits for working memory in patients with posttraumatic stress disorder. Brain Research, 1531, 94-101. 